\title{
Pharmacologic activation of peroxisome proliferator-activating receptor-a accelerates hepatic fatty acid oxidation in neonatal pigs
}

\author{
Kwanseob Shim ${ }^{1,2}$, Sheila Jacobi ${ }^{1,3}$, Jack Odle ${ }^{1}$ and Xi Lin ${ }^{1}$ \\ ${ }^{1}$ Laboratory of Developmental Nutrition, Department of Animal Sciences, North Carolina State University, Raleigh, NC 27695, \\ USA \\ ${ }^{2}$ Current/Present address: Department of Animal Biotechnology, Chonbuk National University, Jeonju, 561-756 Republic of Korea \\ ${ }^{3}$ Current/Present address: Ohio Agricultural Research and Development Center, The Ohio State University, Wooster, OH 44691, USA \\ Correspondence to: Xi Lin, email: lin_xi@ncsu.edu
}

Keywords: pig; liver; PPARa; clofibrate; fatty acid oxidation

Received: August 30, $2017 \quad$ Accepted: April 02, $2018 \quad$ Published: May 08, 2018

Copyright: Shim et al. This is an open-access article distributed under the terms of the Creative Commons Attribution License 3.0 (CC BY 3.0), which permits unrestricted use, distribution, and reproduction in any medium, provided the original author and source are credited.

\section{ABSTRACT}

Up-regulation of peroxisome proliferator-activating receptor-a (PPARa) and increasing fatty acid oxidation are important for reducing pre-weaning mortality of pigs. We examined the time-dependent regulatory effects of PPARa activation via oral postnatal clofibrate administration $(75 \mathrm{mg} /(\mathrm{kg}-\mathrm{BW} \cdot \mathrm{d})$ for up to 7 days) on mitochondrial and peroxisomal fatty acid oxidation in pigs, a species with limited hepatic fatty acid oxidative capacity due to low ketogenesis. Hepatic oxidation was increased by $44-147 \%$ (depending on fatty acid chain-length) and was attained after only 4 days of clofibrate treatment. Acyl-CoA oxidase (ACO) and carnitine palmitoyltransferase I (CPTI) activities accelerated in parallel. The increase in CPTI activity was accompanied by a rapid reduction in the sensitivity of CPTI to malonylCOA inhibition. The mRNA abundance of CPTI and ACO, as well as peroxisomal keto-acyl-CoA thiolase (KetoACOA) and mitochondrial malonyl-CoA decarboxylase $(M C D)$, also were augmented greatly. However, the increase in ACO activity and MCD expression were different from CPTI, and significant interactions were observed between postnatal age and clofibrate administration. Furthermore, the expression of acetyl-CoA carboxylase $\beta(A C C \beta)$ decreased with postnatal age and clofibrate had no effect on its expression. Collectively these results demonstrate that the expression of PPARa target genes and the increase in fatty acid oxidation induced by clofibrate are time- and age-dependent in the liver of neonatal pigs. Although the induction patterns of $C P T I, M C D, A C O, K e t o A C O A$, and $A C C \beta$ are different during the early postnatal period, 4 days of exposure to clofibrate were sufficient to robustly accelerate fatty acid oxidation.

\section{INTRODUCTION}

Milk fat is a critical macronutrient for the fast growth and development of all mammalian neonates after birth. During the postnatal period of newborn pigs, milk fat becomes the principal substrate for oxidative metabolism, comprising $60 \%$ of dietary energy [1].
However, available evidence suggests that the neonatal piglet has a limited capacity to catabolize dietary fatty acids, and a one-day-old pig oxidizes fatty acids at only $32 \%$ of the rate of a 24-day-old pig [2]. Metabolic studies with cells have shown that $90 \%$ of oleate taken up by piglet hepatocytes is re-esterified with a limited flux through $\beta$-oxidation [3]. Moreover, suckling piglets 
are hypoketonemic despite elevated dietary fat $[4,5]$. Therefore, the postnatal regulation of fatty acid oxidation has been studied in newborn piglets to understand milk fat utilization [6-9]. Results indicate that the limited capacity of piglets to utilize fatty acids is in part associated with mutated gene transcription and translation [6-9], as well as the unique protein structures of key enzymes in the fatty acid oxidative pathway [10].

Peroxisome proliferator-activating receptor- $\alpha$ (PPAR $\alpha$ ) is an essential transcription factor in regulating hepatic fatty acid oxidation. PPAR $\alpha$ controls the genes encoding carnitine palmitoyltransferase I (CPTI) [11], mitochondrial 3-hydroxy-3-methyl-glutaryl-CoA synthase (mHMGCS) [12], acyl-CoA oxidase (ACO) [13] and malonyl-CoA decarboxylase (MCD) [14]. The PPAR $\alpha$ response element has been identified within the promoters of these genes. Increasing their transcription via PPAR $\alpha$ activation increases mitochondrial and peroxisomal fatty acid oxidation [15]. This involves not only the up-regulation of mitochondrial and peroxisomal genes (mainly those involved in $\beta$-oxidation), but also an increase in peroxisomal size and the biogenesis of peroxisomes [16]. In mice and rats, PPAR $\alpha$ is highly expressed in tissues that have high fatty acid catabolic rates, including the liver, kidney, heart, and skeletal muscle [17]. The critical role of PPAR $\alpha$ in controlling fatty acid oxidation and its activation under different physiological adaptation, fasting and refeeding transition, development and aging $[18,19]$ and pathological conditions such as in alcoholic liver disease [20] and breast cancer [21] have been studied extensively. Contrasted against rodent species, however, PPAR $\alpha$ inductive genes for peroxisomal fatty acid oxidation are not highly expressed and peroxisomal proliferation is not sensitive to PPAR $\alpha$ activation in weaned pigs [22] and newborn pigs after birth even though milk fat is the primary energy source. The regulatory role of PPAR $\alpha$ in fatty acid oxidation in pigs has not been well explored during the neonatal period.

Perinatal programming of metabolism is very dynamic and continues during the early postnatal period. We previously examined the effects of activation of PPAR $\alpha$ by clofibrate, the hypolipidemic drug used in human clinical medicine for many years [23], on fatty acid metabolism and milk fat utilization in pigs. As a synthetic PPAR $\alpha$ agonist, clofibrate is well known for decreasing circulating lipids, including LDL-cholesterol, and for increasing fatty acid oxidation [24]. Indeed, in concurrent (unpublished) work we confirmed that clofibrate reduced circulating cholesterol (by 33\%) and triglycerides (by $26 \%$ ) while maintaining normoglycemia $(110 \mathrm{mg} / \mathrm{dL}$; data not shown) in suckling pigs. We showed that clofibrate effectively stimulated in vitro fatty acid oxidation in tissue homogenates and hepatocytes isolated from newborn pigs [25] and in vivo oxidation in neonatal pigs following orogastric gavage [26]. Most recently we showed that fatty acid oxidation was increased in newborn pigs after their dams were fed clofibrate during the last week of gestation [27]. The results from our studies demonstrated that PPAR $\alpha$ activation indeed played an important role in fatty acid oxidative metabolism in pigs during the fetusto-newborn transition and suckling periods. However, the kinetics of PPAR $\alpha$ induction of fatty acid oxidation was not examined in previous studies. We hypothesized that piglet age and duration of clofibrate administration could be important for optimizing induction of fatty acid oxidation. Furthermore, induction of genes controlling fat oxidation such as $C P T I$, acetyl-CoA carboxylase $(A C C)$, and $M C D$ has not been examined synchronously as factors affecting oxidation rate.

The work reported herein was designed to better define the time- and age-dependent effects of PPAR $\alpha$ activation via postnatal clofibrate administration on fatty acid oxidation. The potential effects of inhibiting CPTI activity on gene expressions of CPTI and ACO induced by PPAR $\alpha$ activation were evaluated via administration of etomoxir, an irreversible inhibitor of the CPTI enzyme located on the outer face of the inner mitochondrial membrane. The effects of malonyl-CoA on the fatty acid oxidation regulation were also investigated via examining $A C C$ and $M C D$ gene expression. A practical consideration of this research is that it would allow the agonist to be directed specifically to high-risk piglets at risk of energy deficiency. Therefore, the effect of clofibrate on gene expression and activity of lipid-metabolizing enzymes was determined in the liver of pigs at different postnatal ages.

\section{RESULTS}

\section{Growth performance (body weight, weight gain and liver weight)}

Supplementation of clofibrate (Clo) or clofibrate with etomoxir (Clo+Eto) had no effects on initial body weight $(\mathrm{P}=0.87)$, end body weight $(\mathrm{P}=0.87)$, body weight gain $(\mathrm{P}=0.88)$, daily gain $(\mathrm{P}=0.99)$, and the ratio of gain/milk consumed $(\mathrm{P}=0.88)$, nor were any differences detected in quantitative image analysis of the liver histology sections (data not shown). The average initial body weight, end body weight, body weight gain, daily gain and ratio of gain/milk consumed were on average $1432.7 \mathrm{~g}, 1848.9 \mathrm{~g}, 366.1 \mathrm{~g}, 70.8 \mathrm{~g}$ and 0.05 , separately. The average weight gain $(\mathrm{g})$ from $\mathrm{d} 1$ (16.6) to $\mathrm{d} 7$ (812.9) and milk intake (g) from d 1(155) to $\mathrm{d} 7$ (748.9) increased with increasing of postnatal age $(\mathrm{P}<0.004)$. There were no effects of $\mathrm{Clo}$ or $\mathrm{Clo}+$ Eto on liver weight $(\mathrm{P}=0.12)$. Liver weights (from 36 to $40 \mathrm{~g}$ ) also increased with increasing body weights $(\mathrm{P}<0.004)$, but relative weight $(\%$ of body weight $)$ did not change $(\mathrm{P}=0.42)$ during the experiment. No interactions between treatment and piglet age were detected $(\mathrm{P}=0.24)$. 
Table 1: Plasma ketone body, total free fatty acid and insulin concentrations from pigs that received vehicle (Con), clofibrate (Clo) or clofibrate + etomoxir (Clo+Eto) during postnatal period ${ }^{*}$

\begin{tabular}{|c|c|c|c|c|c|c|c|c|c|c|c|c|}
\hline & \multicolumn{4}{|c|}{ Age (day) } & \multirow[t]{2}{*}{ SEM } & \multirow[t]{2}{*}{ P-value } & \multicolumn{3}{|c|}{ Treatments } & \multirow[t]{2}{*}{ SEM } & \multirow[t]{2}{*}{ P-value } & \multirow{2}{*}{$\frac{\text { Age treatment }}{\text { P-value }}$} \\
\hline & $\overline{0}$ & 1 & 4 & 7 & & & Con & Clo & $\overline{\text { Clo+Eto }}$ & & & \\
\hline $\begin{array}{l}\text { AcAc } \\
(\mu \mathrm{mol} / L)\end{array}$ & $9.60^{\mathrm{a}}$ & $22.92^{\mathrm{b}}$ & $21.35^{\mathrm{b}}$ & $23.42^{\mathrm{b}}$ & 1.11 & 0.0001 & 19.31 & 17.81 & 20.85 & 0.97 & 0.097 & 0.48 \\
\hline $\begin{array}{l}\mathbf{K B} \\
(\mu \mathrm{mol} / \mathrm{L})\end{array}$ & $19.73^{\mathrm{a}}$ & $31.09^{b}$ & $31.23^{\mathrm{b}}$ & $34.95^{\mathrm{b}}$ & 1.36 & 0.031 & 28.73 & 28.30 & 31.47 & 0.13 & 0.13 & 0.33 \\
\hline $\begin{array}{l}\text { TFFA } \\
(\mathrm{mmol} / \mathrm{L})\end{array}$ & $0.044^{\mathrm{a}}$ & $0.039^{\mathrm{a}}$ & $0.053^{\mathrm{a}}$ & $0.077^{b}$ & 0.007 & 0.0014 & 0.061 & 0.059 & 0.048 & 0.007 & 0.36 & 0.74 \\
\hline $\begin{array}{l}\text { Insulin } \\
(\mu g / L)\end{array}$ & 0.035 & 0.033 & 0.036 & 0.036 & 0.002 & 0.52 & 0.035 & 0.035 & 0.035 & 0.001 & 0.91 & 0.29 \\
\hline
\end{tabular}

*There was no interaction between age and treatment. The main effects of age (day) and treatment (Con, Clo and Clo+Eto) were presented in the table. Values are means \pm SEM for 6 blocks in each age / treatment group. Means without a common letter differ, $\mathrm{P}<0.05$. AcAc, acetoacetate; $\mathrm{KB}$, total ketone bodies $(\mathrm{KB}=\beta$-hydroxybutyrate $+\mathrm{AcAc})$ and TFFA, total free fatty acid.

\section{Plasma ketone body, free fatty acid and insulin concentrations}

The average concentration of acetoacetate (AcAc) in plasma of pigs after $\mathrm{d} 1$ was 2.3 fold higher than that at birth, but there were no differences among $d 1$, 4 and 7. The treatment effect on AcAc concentration and interaction of the treatment with age were not detected (Table 1). Similarly, the average concentration of total ketone bodies $(\mathrm{KB}=\beta$-hydroxybutyrate $(\mathrm{BHB})$ $+\mathrm{AcAc}$ ) should be increased $66 \%$ after day 1 , but no treatment effect or interaction were detected (Table 1). Age and treatment had no effect on plasma insulin concentration. The plasma concentration measured in all pigs on average was $0.035 \mu \mathrm{g} / \mathrm{L}$ (Table 1). Plasma total free fatty acid (TFFA) increased with advancing postnatal age. The concentration $(\mathrm{mmol} / \mathrm{L})$ of TFFA was $45 \%$ higher in pigs on $\mathrm{d} 7$ than $\mathrm{d} 4$ and $100 \%$ higher than that on $\mathrm{d} 0$ and 1 . Neither Clo nor Clo+Eto had an impact on plasma TFFA, and no interactions with age were observed (Table 1). Plasma BHB was impacted by postnatal age from $\mathrm{d} 1$ to $7(\mathrm{P}<0.031)$. The average concentration $(\mu \mathrm{mol} / \mathrm{L})$ from all treatments determined at $\mathrm{d} 7$ was $19 \%$ greater than that determined at birth, $\mathrm{d}$ 1 and $\mathrm{d} 4$ (Figure 1A). There was no detectable effect of treatment on BHB, but the interaction of age with treatment was significant $(\mathrm{P}<0.013)$. Treatments with Clo or Clo+Eto increased plasma BHB by $38 \%$ over Con by d7 (Figure 1A).

\section{Enzyme activities}

Hepatic CPTI specific activity (Table 2) increased after 24 hours. The activities ( $\mu \mathrm{mol} /(\mathrm{h} \cdot \mathrm{mg}$ protein)) measured on d 1, 4 and 7 were on average 1.9 fold greater than the activity measured in newborns. Administration of Clo stimulated CPTI activity by 1.65 fold of that in Con pigs. Administration of Clo+Eto attenuated the Clo stimulation to Con levels. The sensitivity of CPTI to malonyl-CoA inhibition was impacted by age and Clo (Supplementary Figure 1). The malonyl-CoA inhibition constants $\left(\mathrm{IC}_{50}\right)$ were on average $62 \%$ higher at $\mathrm{d} 7$ than at d 1 and 4 , and $37 \%$ greater from Clo treated pigs than Con pigs (Table 2). Feeding Clo+Eto to piglets had no effect on the $\mathrm{IC}_{50}$. The $\mathrm{IC}_{50}$ value measured in newborn pigs was $84 \%$ greater than that measured in Con pigs on $\mathrm{d} 1$ and 4 , but there was no difference between newborns and 7-d-old pigs. No interaction between age and treatment was detected for CPTI activity or $\mathrm{IC}_{50}$ values (Table 2).

Hepatic ACO specific activity was impacted by both age and treatment (Figure 1B). The activity increased with postnatal age regardless of treatment groups (Figure 1B). The interaction between treatment and age was also significant $(\mathrm{P}<0.001)$. In Con pigs, the activity $(\mu \mathrm{mol} / \mathrm{mg}$ protein) determined in newborns was increased by 3.2 and 31.2 fold on $\mathrm{d} 1$ and 4 . However, the activity measured on $\mathrm{d} 7$ was not different from that measured on $\mathrm{d} 4(\mathrm{P}=0.23)$. Clofibrate stimulated ACO activity and the stimulation was 4.1 and 2.7 fold higher in Clo treated pigs than in Con pigs at $\mathrm{d} 1$ and 4 . There was no further stimulation after 4 days. Administration of $\mathrm{Clo}+$ Eto reduced the Clo stimulation by $15-20 \%$ at 1,4 and 7 days of age, but the increase in activity with age was of the same order as the piglets treated with Clo only (Figure 1B).

Hepatic mHMGCS specific activities measured on d 1, 4 and 7 were 2, 2.9, and 2.6 times greater than that measured in newborns $(\mathrm{P}<0.0001)$. The activity tended to increase with postnatal age and was $42 \%$ higher in 7-d-old than 1-d-old pigs ( $\mathrm{P}=0.09)$. Administration of Clo had no effect on the enzyme activity, but addition of Clo+Eto increased the enzyme activity by $44 \%$ as compared to Con. No interaction between age and treatment was observed (Table 2). 

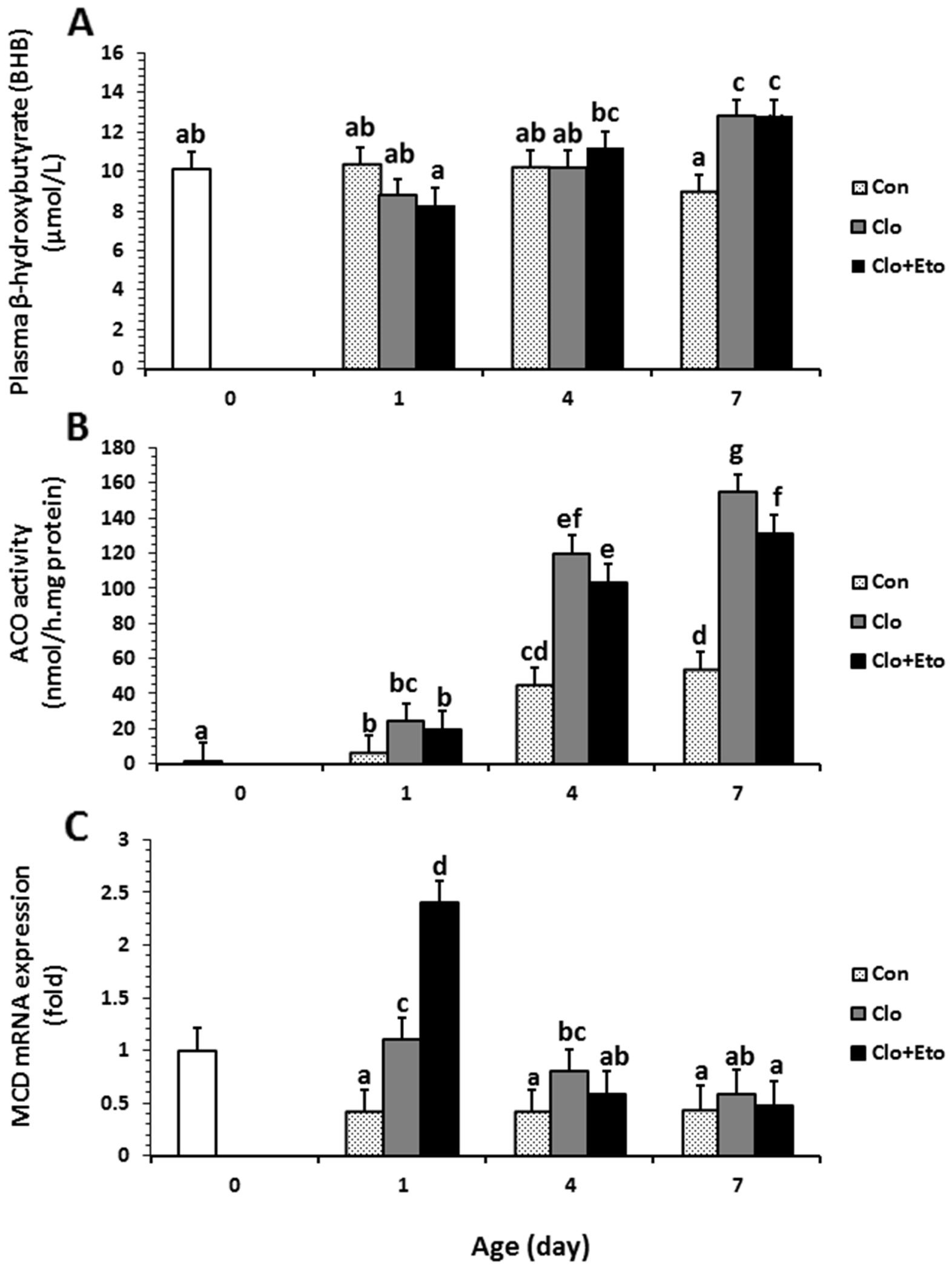

Figure 1: The effects of postnatal age and clofibrate administration on plasma BHB (A) and hepatic ACO activity (B) and MCD gene expression (C). Values obtained from pigs received vehicle (Con), clofibrate (Clo) or clofibrate + etomoxir (Clo+Eto) at age of d 0 ( $\mathrm{n}=6)$, $1(\mathrm{n}=18), 4(\mathrm{n}=18)$ and $7(\mathrm{n}=18)$. For all panels, treatment ${ }^{*}$ age interaction $(\mathrm{P} \leq 0.01)$; values are least square means \pm SEM. Bars lacking a common letter differ $(\mathrm{P}<0.005)$. 
Table 2: Hepatic CPT I and mHMGCS activities from pigs that received vehicle (Con), clofibrate (Clo) or clofibrate + etomoxir (Clo+Eto) during postnatal period ${ }^{*}$

\begin{tabular}{|c|c|c|c|c|c|c|c|c|c|c|c|c|}
\hline \multirow[t]{2}{*}{ Enzymes } & \multicolumn{4}{|c|}{ Age (day) } & \multirow[t]{2}{*}{ SEM } & \multirow[t]{2}{*}{ P-value } & \multicolumn{3}{|c|}{ Treatments } & \multirow[t]{2}{*}{ SEM } & \multirow[t]{2}{*}{ P-value } & \multirow{2}{*}{$\frac{\text { Age treatment }}{\text { P-Value }}$} \\
\hline & $\mathbf{0}$ & 1 & 4 & 7 & & & Con & Clo & Clo+Eto & & & \\
\hline \multicolumn{13}{|c|}{ $\mu$ mol/h.mg protein } \\
\hline $\begin{array}{l}\text { CPTI } \\
\mu \mathrm{mol} / \mathrm{L}\end{array}$ & 30.62 & $73.65^{\mathrm{a}}$ & $100.33^{b}$ & $89.35^{\mathrm{b}}$ & 5.01 & 0.0044 & $71.08^{\mathrm{a}}$ & $117.08^{b}$ & $75.16^{\mathrm{a}}$ & 5.03 & 0.0001 & 0.95 \\
\hline $\begin{array}{l}\mathbf{I C}_{\mathbf{5 0}} \\
\mathrm{nmol} / \mathrm{m} \cdot \mathrm{mg}\end{array}$ & $\begin{array}{c}2.39 \\
\text { protein }\end{array}$ & $1.43^{\mathrm{a}}$ & $1.70^{\mathrm{a}}$ & $2.53^{\mathrm{b}}$ & 0.17 & 0.0004 & $1.25^{\mathrm{a}}$ & $2.23^{\mathrm{b}}$ & $2.18^{\mathrm{b}}$ & 0.18 & 0.001 & 0.25 \\
\hline mHMGCS & 16.25 & 33.32 & 47.00 & 42.46 & 4.36 & 0.094 & $34.84^{\mathrm{a}}$ & $37.89^{\mathrm{a}}$ & $50.06^{\mathrm{b}}$ & 6.11 & 0.046 & 0.63 \\
\hline
\end{tabular}

*There was no interaction between age and treatment. The main effects of age (day) and treatment (Con, Clo and Clo+Eto) were presented in the table. Values are means \pm SEM for 6 animals in each treatment group. Means without a common letter differ, $\mathrm{P}<0.05$.

CPTI, carnitine palmitoyltransferase $\mathrm{I} \mathrm{IC}_{50}$, the half maximal inhibitory concentration of malonyl-CoA (the physiological inhibitor of CPTI) and mHMGCS, mitochondrial 3-Hydroxy-3-methylglutaryl CoA synthase.

\section{Effect of Clo and Clo+Eto administration on peroxisomal and mitochondrial fatty acid oxidation}

Administration of Clo or Clo+Eto impacted hepatic peroxisomal and mitochondrial oxidation of $\mathrm{C} 8: 0, \mathrm{C} 18: 1$ and $\mathrm{C} 22: 1 \mathrm{CO}_{2}$ and $\mathrm{ASP}$, whereas oxidation rates also differed among the fatty acids (Figures 2-4).

Peroxisomal oxidation rate of C8:0 (Figure 2A) was $20 \%$ higher in Clo treated pigs than Con pigs $(\mathrm{P}<0.04)$. Feeding $\mathrm{Clo}+$ Eto attenuated the stimulation by $\mathrm{Clo}$, and the oxidation rate $(\mu \mathrm{mol} / \mathrm{h} \cdot \mathrm{g}$ protein) measured at birth (18.7) was similar to that measured on $\mathrm{d} 1$ (23.2), but was increased by 1.2 and 1.8 fold on $\mathrm{d} 4$ and $7(\mathrm{P}<0.0005)$. No interaction between postnatal age and treatment was observed. In contrast, the Clo induction of mitochondrial C8:0 oxidation (Figure 3A) was age dependent $(\mathrm{P}<$ 0.017). The mitochondrial oxidation rate was $44 \%$ greater in Clo treated pigs than Con pigs on $\mathrm{d} 4$, but no differences between the two groups were detected on $\mathrm{d}$ 1 and 7. Feeding Clo+Eto further increased the oxidation rate and the increase was greater on $\mathrm{d} 7$ (94\%) than $\mathrm{d} 4$ (57\%). Although Clo+Eto influenced both peroxisomal and mitochondrial oxidation, there was no impact on the flux distribution between $\mathrm{CO}_{2}$ and ASP. Neither treatment nor postnatal age had an influence on percentage of peroxisomal oxidation (Figure 4A).

Peroxisomal oxidation rate of C18:1 (Figure 2B) was increased on average by $48 \%$ in Clo treated pigs as compared to Con pigs $(\mathrm{P}<0.0001)$. Feeding Clo+Eto had no effect on the oxidation induced by Clo. With increasing postnatal age, the oxidation rate measured at birth (5.95 $\mathrm{umol} /(\mathrm{h} \cdot \mathrm{g}$ protein)) increased 34 and $147 \%$ on $\mathrm{d} 1$ and $4(\mathrm{P}<0.0001)$. There was no further increase after $\mathrm{d} 4$. Similarly, the oxidation rate of $\mathrm{C} 18: 1$ in mitochondria (Figure 3B) was $85 \%$ greater in Clo treated pigs than
Con pigs $(\mathrm{p}<0.0001)$. Feeding Clo+Eto attenuated the oxidation rate induced by $\mathrm{Clo}$ and the induction $(59 \%)$ was $25 \%$ less as compared to Clo treated pigs $(\mathrm{P}<0.0035)$. The rate also increased with postnatal age as in peroxisomes, and was 1.1 and 3.5 fold higher at $\mathrm{d} 1$ and 4 than at birth. After day 4, the oxidation rate was not increased further (P $=0.61$ ). The percentage of peroxisomal oxidation (Figure 4B) tended to decrease with administration of Clo $(\mathrm{P}<$ 0.059), but did not differ between Clo and Clo+Eto treated pigs $(\mathrm{P}=0.22)$. The percentage of peroxisomal oxidation decreased greatly after birth $(\mathrm{P}<0.0001)$, but the decrease was much less after $\mathrm{d} 4(\mathrm{P}=0.08)$.

Peroxisomal of $\mathrm{C} 22: 1$ (Figure 2C) and mitochondrial oxidation (Figure 3C) followed the same pattern as for C18:1 oxidation. The rate was $48 \%$ greater in Clo treated pigs than Con pigs ( $\mathrm{P}<0.0001)$. Feeding Clo+Eto had no effect on the Clo stimulation. The oxidation rate in mitochondria was also increased by $85 \%$ in pigs fed Clo as compared to Con pigs ( $\mathrm{P}<0.0001)$, but the increase was reduced by $16 \%$ in pigs fed Clo+Eto $(\mathrm{P}<0.0035)$. No interaction between postnatal age and treatment was detected $(\mathrm{P}=0.08)$.

Although Clo greatly stimulated peroxisomal and mitochondrial oxidation rates of all fatty acids, the contribution of peroxisomal oxidation to total oxidation remained unchanged (Figure 4C). The contribution of peroxisomes to beta-oxidation of $\mathrm{C} 18: 1$ and $\mathrm{C} 22: 1$ was reduced after one day, but no effect of postnatal age was observed on peroxisomal oxidation of C8:0.

\section{Effect of Clo and Clo+Eto administration on hepatic gene expression during the neonatal period}

The relative mRNA abundance of $L$-CPTI $\alpha, C P T I I$, $m H M G C S$, KetoACoA, $A C C \beta$ and $M C D$ measured in the 


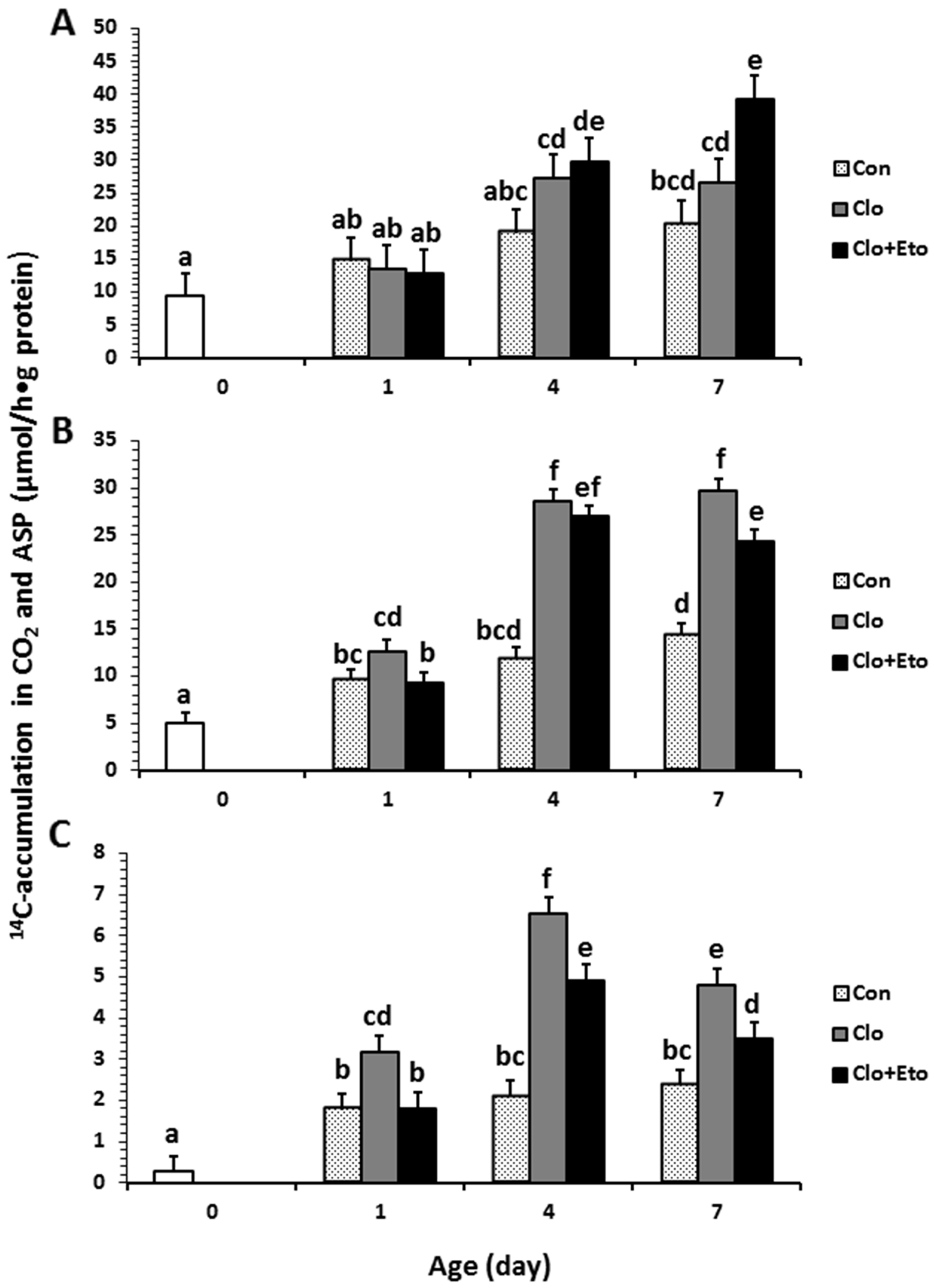

Figure 2: Hepatic peroxisomal fatty acid $\beta$-oxidation measured in pigs received vehicle (Con), clofibrate (Clo) or clofibrate + etomoxir (Clo+Eto). The measurements were conducted in fresh liver homogenates isolated from pigs $(\mathrm{n}=6)$ at $\mathrm{d} 0,1,4$ and 7 using C8:0 (A), C18:1 (B) and C22:1 (C) as substrate. Values are the least square means \pm SEM. Bars lacking a common letter differ $(\mathrm{P}<0.005)$. 


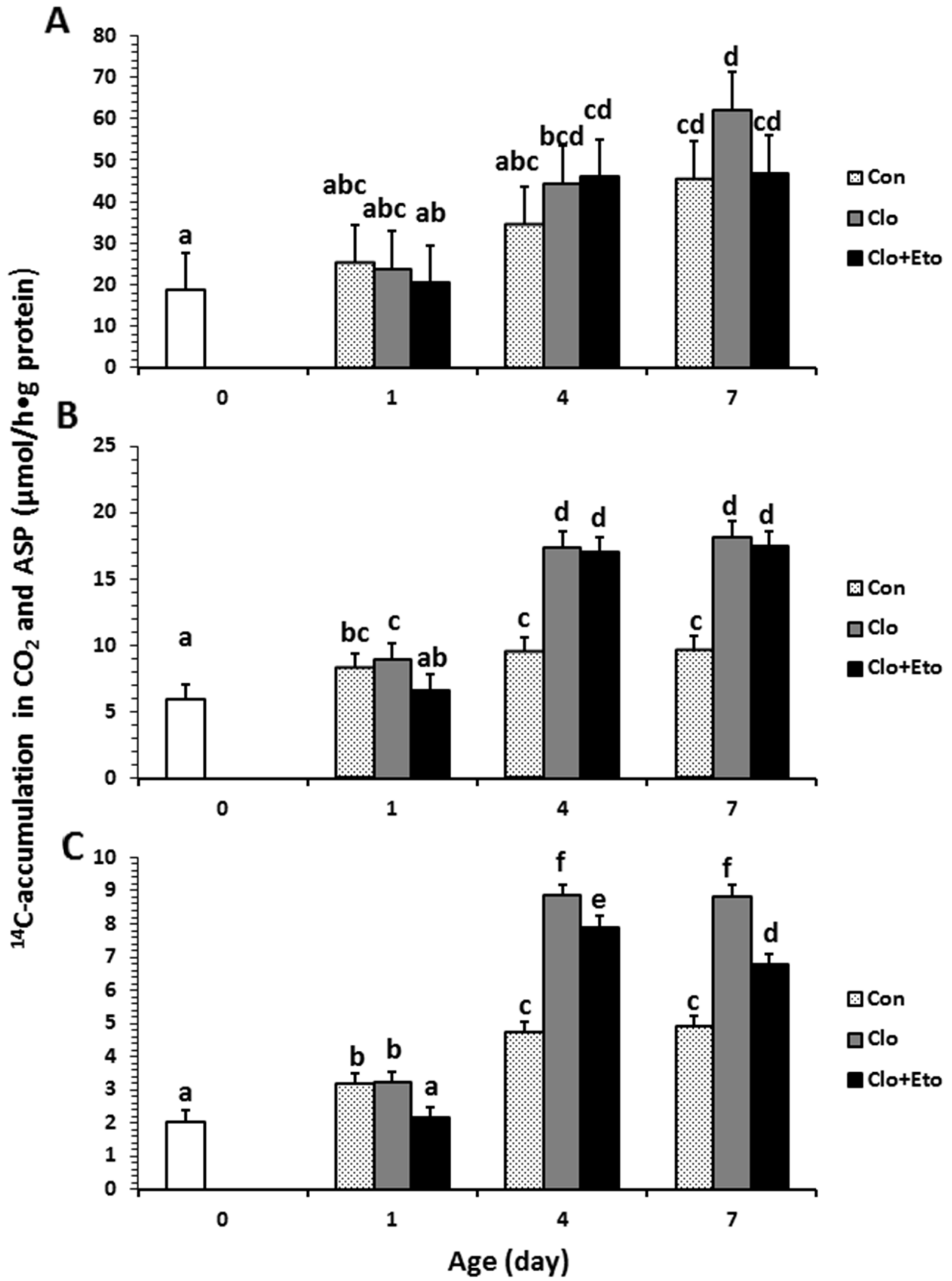

Figure 3: Hepatic mitochondrial fatty acid $\beta$-oxidation measured in pigs received vehicle (Con), clofibrate (Clo) or clofibrate + etomoxir (Clo+Eto). The measurements were conducted in fresh liver homogenates isolated from pigs $(\mathrm{n}=6)$ at $\mathrm{d} 0,1,4$ and 7 using C8:0 (A), C18:1 (B) and C22:1 (C) as substrate. Values are the least square means \pm SEM. Bars lacking a common letter differ $(\mathrm{P}<0.005)$. 


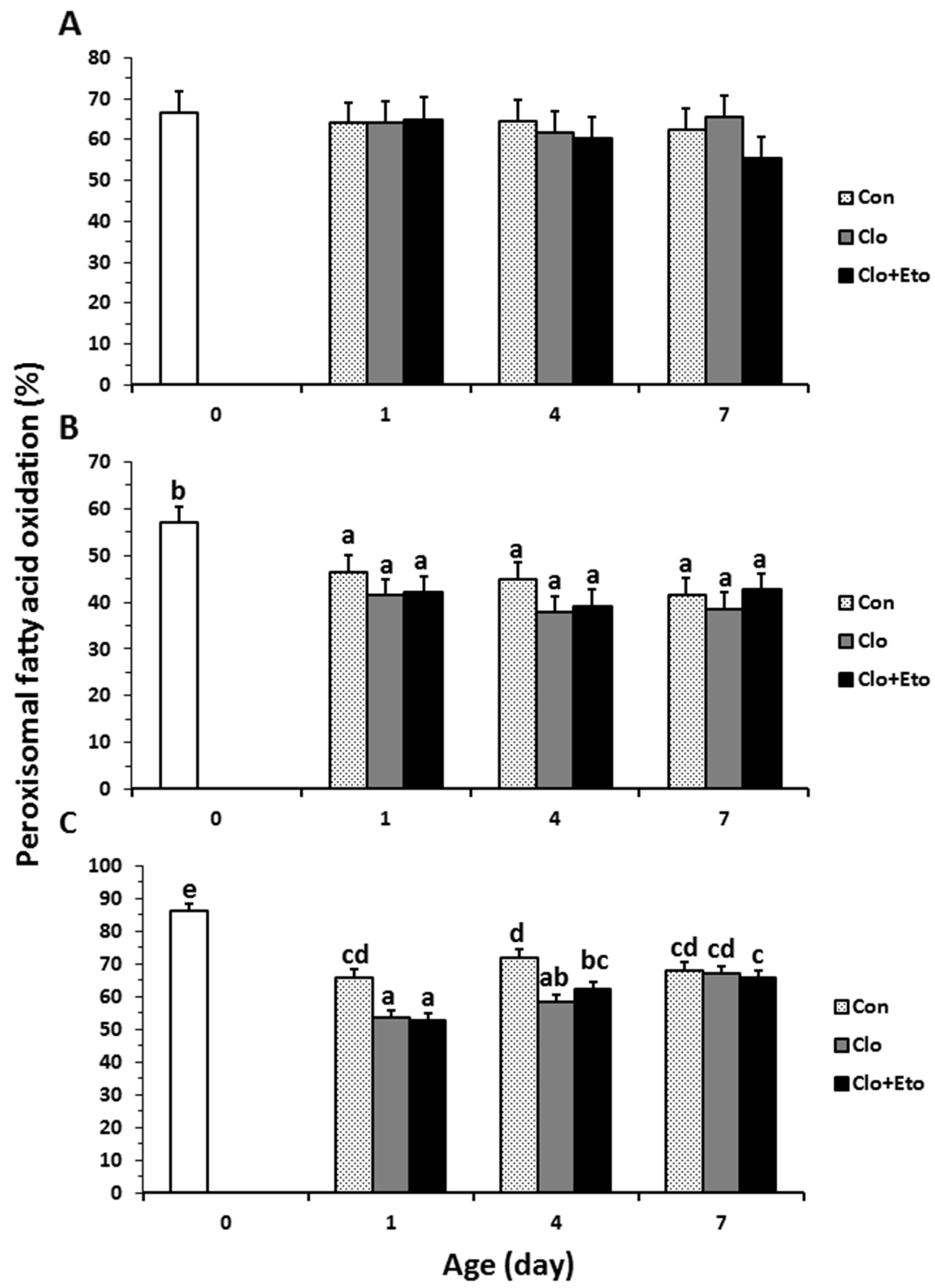

Figure 4: The contributions of peroxisomal $\beta$-oxidation to total fatty acid $\beta$-oxidation in liver from pigs received vehicle (Con), clofibrate (Clo) or clofibrate + etomoxir (Clo+Eto). The percentage was calculated as the accumulation of ${ }^{14} \mathrm{C}(\mathrm{CO} 2+$ ASP) in peroxisomes/the accumulation of ${ }^{14} \mathrm{C}(\mathrm{CO} 2+\mathrm{ASP})$ in both peroxisomes and mitochondria from pigs $(\mathrm{n}=6)$ at $\mathrm{d} 0,1,4$ and 7 using C8:0 (A), C18:1 (B) and C22:1 (C) as substrate. Values are the least square means \pm SEM. Bars lacking a common letter differ $(\mathrm{P}<0.005)$. 
Table 3: Hepatic enrichment of mRNA associated with fatty acid oxidative genes in pigs that received vehicle (Con), clofibrate (Clo) or clofibrate + etomoxir (Clo+Eto) during postnatal period"

\begin{tabular}{|c|c|c|c|c|c|c|c|c|c|c|c|c|}
\hline \multirow[t]{2}{*}{ Genes } & \multicolumn{4}{|c|}{ Age (day) } & \multirow[t]{2}{*}{ SEM } & \multirow[t]{2}{*}{ P-value } & \multicolumn{3}{|c|}{ Treatments } & \multirow[t]{2}{*}{ SEM } & \multirow[t]{2}{*}{ P-value } & \multirow{2}{*}{$\frac{\text { Age }{ }^{*} \text { treatment }}{\text { P-value }}$} \\
\hline & $\mathbf{0}$ & 1 & 4 & 7 & & & Con & Clo & Clo+Eto & & & \\
\hline \multicolumn{13}{|l|}{ fold } \\
\hline L-CPTIa & 1 & $1.14^{\mathrm{a}}$ & $2.21^{\mathrm{b}}$ & $1.65^{\mathrm{b}}$ & 0.28 & 0.032 & $0.72^{\mathrm{a}}$ & $1.97^{\mathrm{b}}$ & $2.30^{\mathrm{b}}$ & 0.28 & 0.0011 & 0.26 \\
\hline L-CРТI $\beta$ & 1 & 1.54 & 1.14 & 0.91 & 0.33 & 0.42 & $0.55^{\mathrm{a}}$ & $1.31^{\mathrm{ab}}$ & $1.74^{\mathrm{b}}$ & 0.33 & 0.052 & 0.15 \\
\hline CPT-II & 1 & $4.24^{\mathrm{a}}$ & $1.93^{\mathrm{b}}$ & $1.25^{\mathrm{b}}$ & 0.73 & 0.020 & $0.98^{\mathrm{a}}$ & $3.06^{\mathrm{ab}}$ & $3.39^{\mathrm{b}}$ & 0.74 & 0.054 & 0.43 \\
\hline ACO & 1 & 0.85 & 0.83 & 0.59 & 0.12 & 0.31 & 0.56 & 0.84 & 0.87 & 0.13 & 0.18 & 0.35 \\
\hline mHMGCS & 1 & $17.94^{\mathrm{a}}$ & $38.22^{b}$ & $21.29^{\mathrm{ab}}$ & 6.10 & 0.05 & $9.54^{\mathrm{a}}$ & $36.95^{b}$ & $30.95^{b}$ & 6.11 & 0.009 & 0.88 \\
\hline PPARa & 1 & 0.81 & 0.78 & 0.56 & 0.13 & 0.42 & 0.56 & 0.85 & 0.73 & 0.14 & 0.35 & 0.34 \\
\hline KetoACoA & 1 & $0.69^{\mathrm{a}}$ & $1.52^{\mathrm{b}}$ & $0.59^{\mathrm{a}}$ & 0.14 & 0.0001 & $0.55^{\mathrm{a}}$ & $1.34^{\mathrm{b}}$ & $0.90^{\mathrm{a}}$ & 0.14 & 0.0023 & 0.12 \\
\hline $\mathrm{ACC} \alpha$ & 1 & 0.41 & 0.29 & 0.27 & 0.06 & 0.17 & 0.26 & 0.30 & 0.41 & 0.06 & 0.19 & 0.44 \\
\hline$A C C \beta$ & 1 & $0.66^{\mathrm{b}}$ & $0.21^{\mathrm{a}}$ & $0.19^{\mathrm{a}}$ & 0.15 & 0.05 & 0.49 & 0.30 & 0.28 & 0.15 & 0.56 & 0.84 \\
\hline
\end{tabular}

${ }^{*}$ There was no interaction between age and treatment. The main effects of age (day) and treatment (Con, Clo and Clo+Eto) were presented in the table. Values are means \pm SEM for 6 animals in each treatment group. Means without a common letter differ, $\mathrm{P}<0.05$. ACO, acyl-CoA oxidase; GAPDH, glyceraldehyde 3- phosphate dehydrogenase; CPT I $\alpha$, hepatic carnitine palmitoyltransferase I; CPT II, hepatic carnitine palmitoyl transferase II; CPTI $\beta$, muscle carnitine palmitoyltransferase I; PPAR $\alpha$, peroxisome proliferators activated receptor $\alpha$; mHMGS, mitochondrial 3-Hydroxy-3-methylglutaryl CoA synthase; ACC $\alpha$, acetyl-CoA carboxylase $\alpha$; ACC $\beta$, acetyl-CoA carboxylase $\beta$ and MCD, malonyl-CoA decarboxylase.

piglets were higher at $\mathrm{d} 4$ than $\mathrm{d} 1$, but no difference was observed between $\mathrm{d} 4$ and 7. Postnatal age had no effects on the mRNA abundance of $A C O, P P A R \alpha, L-C P T I \beta$ or $A C C \alpha$. Supplementation of Clo increased the relative abundance of L-CPTI $\alpha$ (2.7 fold), mHMGCS (3.9 fold) and KetoACoA (2.4 fold) compared to Con, while supplementation of Clo+Eto had no effect on relative transcript abundance of $L-C P T I \alpha$ and $m H M G C S$ induced by clofibrate. However, addition of Clo+Eto increased the mRNA abundance of CPTII and L-CPTI $\beta$, and reduced the expression of KetoACoA compared to treatment with Clo alone (Table 3).

Supplementation of Clo increased the relative abundance of $M C D$ (2.0 fold) compared to Con, but supplementation of Clo+Eto had no effect on the $M C D$ expression induced by Clo. An interaction also was observed between treatment and postnatal age for the mRNA abundance of $M C D(\mathrm{P}<0.001)$. The administration of Clo stimulated the mRNA expression on $\mathrm{d} 1$, but not on $\mathrm{d} 4$ and 7 . The stimulation was greater in pigs with Clo+Eto than with Clo alone. No differences were detected among other treatments (Figure 1C).

\section{DISCUSSION}

Piglet mortality remains high through the first week of life [28], and perinatal programming of energy metabolism is very dynamic, continuing during the early postnatal period. Thus, both the age of the pig and the duration of Clo administration could be important for maintaining high energy utilization. Gene expression induced by Clo changes markedly in adult rats during 14 days of continues treatment, with the highest stimulation for several fatty acid oxidative genes observed by 7 days [29], which implies that the induction of energy utilization could be influenced by the time and duration of Clo administration. Therefore, this experiment was designed to better define the time-dependent effects of postnatal PPAR $\alpha$ activation by Clo administration immediately after birth in the suckling pig model.

Consistent with our previous studies [26, 27, 30], Clo administration significantly increased hepatic fatty acid oxidative capacity. The increase was driven by increased CPTI and ACO activities induced by the administration of Clo. The induction followed the same kinetic pattern as the enzymes during early postnatal development (Supplementary Figure 2). The activity showed a burst around $4 \mathrm{~d}$ of age and a steady state phase after $\mathrm{d} 4$ based on the rate of fatty oxidation measured in this study (Table 2). The postnatal fatty acid oxidation rate followed the same pattern as the enzyme activities. The stimulation by Clo was independent of postnatal age. A linear relationship was observed between the enzyme activity and fatty acid oxidation in both mitochondria and peroxisomes (Supplementary Figure 3). This result indicates that the increase in fatty acid oxidation during the neonatal period induced by Clo is time dependent. A maximum induction would be reached at $4 \mathrm{~d}$ of age. The addition of Eto, the inhibitor of CPTI, to the pigs treated with Clo indeed reduced the enzyme activity and impacted longchain fatty acid oxidation in mitochondria. Similar inhibitory 
responses were observed also for ACO activity and fatty acid oxidation in peroxisomes. Moreover, the inhibitory impact was related to postnatal age and fatty acid chain length. Interestingly, the inhibitory effect of Eto on ACO activity has never been reported, but both stimulation and inhibition of Eto on PPAR a and ACO gene expression was observed in rats and mice under different experimental conditions [31, 32]. Compared with rodent species, pigs receiving Clo or Clo with Eto showed no effects on the expression of PPAR $\alpha$ and $A C O$ genes. This difference could point to species differences or could be due to administration of Eto with Clo.

Medium-chain fatty acid (C8:0) oxidation increased linearly with postnatal age. The impact of administration of Clo and Clo+Eto on C8:0 oxidation was associated with postnatal age and was greater in pigs at $\mathrm{d} 4$ and 7 than at d 1 . However, the ratio of peroxisomal and mitochondrial oxidation for C8:0 remained unchanged. Inhibition of CPTI activity by addition of Eto did not reduce the C8:0 oxidation in mitochondria, suggesting that $\mathrm{C} 8: 0$ oxidation occurred without CPTI and thus the stimulation of Clo must be via enzymes within the inner mitochondria and peroxisomes. Indeed, both mitochondrial medium-chain acyl-CoA dehydrogenase $(M C A D)$ and peroxisomal ketoacyl-CoA thiolase (KetoACoA) have been confirmed to be PPAR $\alpha$ target genes in the liver of mice [33]. Though we did not measure the expression of $M C A D$ in this study, the mRNA enrichment of KetoACoA was increased significantly in pigs treated with Clo.

Administration of Clo increased both C18:1 and C22:1 oxidation in peroxisomes and mitochondria, but the increase was correlated to the chain-length and was relatively greater in mitochondria than peroxisomes. Moreover, the ratio of peroxisomal and mitochondrial oxidation was significantly reduced with postnatal age. Administration of Clo or Clo+Eto had no influence on the ratio of peroxisomal and mitochondrial oxidation. Similar results were observed using the same substrates in our previous in vivo study [26]. Treatment with Clo+Eto for $7 \mathrm{~d}$ reduced oxidation of $\mathrm{C} 18: 1$ and $\mathrm{C} 22: 1$, but the reduction of $\mathrm{C} 18: 1$ occurred in both mitochondria and peroxisome, while the reduction of C22:1 occurred only in peroxisomes. These data confirmed that longchain fatty acid can be oxidized in both mitochondria and peroxisomes and the oxidation in mitochondria can be increased by the CPTI. The preference of long-chain fatty acid oxidation in peroxisomes increased with the chain-length. The percentage of C22:1 (63.0) oxidation in peroxisomes was $40 \%$ greater than that of $\mathrm{C} 18: 1(45.5)$.

Along with the significant increase in the activities of the key enzymes (CPTI \& ACO), the mRNA enrichment of CPTI increased with postnatal age and Clo administration, which was similar to our previous observation [26]. In addition to CPTI, the mRNA enrichment of CPTII was also increased with the postnatal age and administration of Clo. The addition of Eto had no influence on its expression. However, the increases in mRNA enrichment of $A C O$ and
PPAR $\alpha$ from pigs receiving Clo were not observed when expressed as fold-change versus pigs at birth ( 0 age), which was also consistent with results observed in our previous work [26]. Because the gene expression might be sensitive to the age and physiological status, all the pigs used in this study were 12-h fasted pigs. Similar results were observed in piglets born to dams fed Clo during gestation [27], demonstrating that transplacental induction is possible. Thus, the changes in $A C O$ and PPAR $\alpha$ gene expression were associated with age and fasting status. Indeed, the influence of the interaction between postnatal age and Clo administration was observed on ACO activity. Furthermore, the induction of peroxisomal $\beta$-oxidation by Clo in pigs was smaller as compared to rodent species [30].

Postnatal age and Clo with no Eto had no effect on the activity of mHMG-CoA despite their large stimulation of its mRNA abundance. Nonetheless, plasma ketone bodies (both KB and AcAc) increased with postnatal age.

Administration of Clo not only increased CPTI activity but also reduced the sensitivity of CPTI to malonylCoA inhibition, while the addition of Eto had no influence on the sensitivity reduction caused by Clo. Because the crystal structure of porcine CPTI has not been elucidated, the underlying mechanism could not be drawn from this study. It was reported that the isomers of CPTI $\alpha$ and CPTI $\beta$ in pigs were different from human and rodent species, affecting their affinity for carnitine and the sensitivity to mlaonylCoA inhibition [34]. Because pig CPTI $\alpha$ behaves as CPTI $\beta$ in human and rodent species, we measured the abundance of CPTI mRNA using specific primers designed for CPTIa and $C P T I \beta$ (Supplementary Table 1). Both pig CPTI $\alpha$ and $C P T I \beta$ were expressed in the liver. The expression of $C P T I \alpha$ increased with age and Clo treatment, while the $C P T I \beta$ message was unaffected by age, but was increased with supplementations of Clo and Eto. Similar stimulatory effects of Eto on CPTI gene expression were observed in primary cultures of rat hepatocytes [35]. Whether the changes in expression of CPTI $\beta$ were associated with the decrease in sensitivity of CPTI to malonyl-CoA inhibition is not known. However, the finding of both CPTI $\alpha$ and CPTI $\beta$ expression in the liver merits further investigation, as does the observed reduction of CPTI sensitivity to malonyl-CoA inhibition and the mechanism of action of Eto.

There is only limited information regarding MCD and ACC $\beta$ in the liver of swine, but several lines of evidence suggest that MCD and ACC $\beta$ may play an important role in regulating hepatic fatty acid oxidation in pigs. First, lipogenesis activity in the liver is extremely low in swine [36], and the contribution of lipogenesis to lipid synthesis from liver is minimal for this species compared to rats, rabbits and humans [37], suggesting that the amount of malonyl-CoA produced is extremely low in pig liver. Second, results from our previous data [38] indicated that liver CPTI activity is highly sensitive to inhibition by malonyl-CoA in neonatal piglets, and hepatic fatty acid oxidation is increased significantly when the malonyl- 
CoA concentration is decreased, suggesting that malonylCoA generated mainly by ACC $\beta$ might serve as the major signaling molecule for metabolic control of fatty acid $\beta$-oxidation. Third, inhibition of MCD increases the malonyl-CoA concentration and reduces fatty acid oxidation in pig heart in vivo [39], suggesting that malonyl-CoA concentration can be decreased via degradation of malonylCoA by MCD. Although the lipogenesis activity is low, it has been shown that both $A C C \alpha$ and $A C C \beta$ are expressed in this species $[40,41]$. To explore the regulatory roles of ACC $\beta$ and MCD in fatty acid metabolism via malonylCoA, the expressions of both $A C C \alpha$ and $A C C \beta$ were measured in this study and the enrichment of $A C C \beta$ was significantly reduced with postnatal age. Because ACC $\alpha$ maintains regulation of fatty acid synthesis whereas ACC $\beta$ mainly regulates fatty acid oxidation [42], this finding indicated that ACC is indeed involved in the regulation of fatty acid oxidation postnatally. Administration of Clo or Clo with Eto had no influence on either $A C C \alpha$ or $A C C \beta$ expression. Campbell and coworkers [43] reported that $A C C \beta$ expression is not associated transcriptionally with PPAR $\alpha$, but is controlled by sterol regulatory elementbinding protein-1 in the liver. Therefore, the result obtained in pig liver contrast observations in rodents. In support of our hypothesis on the role of MCD in fatty acid oxidation, we also found that the expression of $M C D$ mRNA was increased significantly in the liver of the pigs receiving Clo, but the increase was associated with postnatal age. The enzyme MCD degrades malonyl-CoA, the physiological inhibitor of CPTI, thus the increase of fatty acid oxidation during the postnatal period could be associated with a reduction in malonyl-CoA concentration due to the activation of MCD, the reduction of $A C C \beta$, or both.

In conclusion, there are no interactions between postnatal age and PPAR $\alpha$ activation and expression of its target genes of $A C O$, KetoACoA, CPTI and $m H M G C S$ in liver of neonatal pigs. The increased fatty acid oxidation and expression of PPAR $\alpha$ target genes induced by PPAR $\alpha$ activation are time-dependent in the liver of neonatal pigs. Postnatal changes in $A C C$ and modification of $M C D$ by PPAR $\alpha$ activation observed in this study demonstrated that malonyl-CoA plays an important role in regulation of fatty acid oxidation even though hepatic fatty acid synthesis is very low in pigs. The gene expressions of CPTI $\alpha$ and $C P T I \beta$ detected in the liver might imply that the sensitivity of CPTI to malonyl-CoA inhibition is associated with the expressions of the two isomers, but further study is needed to confirm this hypothesis.

\section{MATERIALS AND METHODS}

\section{Animals, treatments and experimental design}

Sixty newborn pigs (colostrum-deprived) were obtained from the North Carolina State University Swine Education Unit at 12 to $24 \mathrm{~h}$ of age. Pigs (1.43 $\pm 0.06 \mathrm{~kg}$ ) from 6 litters containing 10 pigs each were used in this experiment. One pig from each litter was selected randomly as a newborn control (New) for sample collection and the remaining nine pigs from each litter were allocated into three treatments by initial body weight (with 3 littermates per treatment). Pigs either received vehicle ( $2 \%$ Tween 80 ; control, Con), clofibrate (Clo) or clofibrate plus etomoxir (Clo+Eto) in the vehicle once daily via intragastric gavage for up to 7 days. To characterize the roles of CPTI and ACO activities in the increased fatty acid oxidation induced by PPAR $\alpha$ activation, etomoxir was used in the treatment of $\mathrm{Clo}+$ Eto. Etomoxir is not only an irreversible inhibitor of CPTI [44], but also stimulates $A C O$ expression [31]. The clofibrate daily dosage was $75 \mathrm{mg} / \mathrm{kg}$ body weight based on our previous research [26] and the daily etomoxir dosage was $25 \mathrm{mg} / \mathrm{kg}$ body weight [45] in $5 \mathrm{~mL}$ of the vehicle. All pigs were housed individually in cages in an environmentally controlled facility at $30^{\circ} \mathrm{C}$. Pigs were fed colostrum substitute (Colostrum Plus; La Belle Associates, Inc, Bellingham, WA 98226) for $12 \mathrm{~h}$, and then fed milk replacer (containing spray-dried choice white grease as the lipid source) and formulated to containing 25\% fat, $31 \%$ crude protein, and $36 \%$ lactose. Diet was prepared daily and stored under refrigeration, and fresh milk was offered via gravity flow through a nipple to pigs three times per day. Pigs were fed precisely according to a prescribed plan of intake that we had developed ( $\sim 60 \%$ ad libitum) to match growth rates of sow-reared pigs. Body weights and milk intakes were recorded daily. All procedures were approved by the North Carolina State University Animal Care and Use Committee.

\section{Tissue sampling and preparation}

Pigs were fasted for $12 \mathrm{~h}$ and then euthanized by American Veterinary Medical Association (AVMA)approved electrocution at 1,4 and 7 days of age. In addition, 6 newborn pigs (one from each litter) were euthanized immediately at birth to serve as day-0 controls. Blood samples were collected and plasma obtained by centrifugation at $2000 \times \mathrm{g}$ for $15 \mathrm{~min}$. Liver was removed and weighed immediately, and portions were placed in ice-cold isolation buffer for analyses of CPTI activity in freshly isolated mitochondria and of fatty acid $\beta$-oxidation in freshly prepared homogenate. The mitochondria isolation and homogenate preparation procedures were performed as described by Natarajan et al. (2006) [46]. Mitochondrial and homogenate protein concentrations were determined using the Biuret method [47]. Additional liver samples were formalin-fixed for histology examination as described by Cheon et al. (2005) [22]. Liver samples and isolated mitochondrial fractions also were frozen immediately in liquid nitrogen and stored at $-80^{\circ} \mathrm{C}$ for mHMGCS activity and ACO activity and gene expression determinations. 


\section{Plasma analysis}

Plasma free fatty acids were analyzed using a kit from BioVision (Catalog\# K612-100), and plasma ketone bodies were determined using the procedure as described by Kientsch-Engel and Siess [48]. Plasma insulin was determined using an ELISA kit (Mercodia Inc.; USA).

\section{Analysis of enzymes}

\section{CPTI activity and its sensitivity to malonyl-CoA inhibition}

CPTI activity in liver mitochondria was determined following the procedure described by Bremer et al. [49] with a slight modification [38].

\section{Acyl-CoA oxidase activity}

Acyl-CoA oxidase activity was assayed by the fluorometric measurement of $\mathrm{H}_{2} \mathrm{O}_{2}$ using the modified method previously reported by Walusimbi-Kisitu and Harrison (1983) [50]. Reactions with $50 \mu \mathrm{L}$ homogenate containing about $100 \mu \mathrm{g}$ of protein were protected from light for $10 \mathrm{~min}$ at $37^{\circ} \mathrm{C}$ with shaking. Assays were started by addition of $35 \mu \mathrm{mol} / \mathrm{L}$ palmitoyl-CoA after preincubation for $10 \mathrm{~min}$ and terminated by adding $4 \mathrm{~mL}$ of $0.1 \mathrm{~mol} / \mathrm{L}$ borate buffer, $\mathrm{pH} 10$ and fluorescence was read at an excitation wavelength of $395 \mathrm{~nm}$ and an emission wavelength of $470 \mathrm{~nm}$. Enzyme activity was expressed as nmol $\mathrm{H}_{2} \mathrm{O}_{2} /(\min \cdot \mathrm{mg}$ tissue protein).

\section{3-hydroxy-3-methylglutaryl CoA synthase activity}

mHMGCS activity was measured at $30^{\circ} \mathrm{C}$ as described by Quant et al. (1989) [51]. The activity was determined by measuring the disappearance of the enol form of acetoacetyl-CoA by monitoring the absorbance at $303 \mathrm{~nm}$ for 30 seconds on a spectrophotometer (Beckman DU 600, Fullerton, CA). The absorption coefficient of acetoacetyl-CoA under the conditions used $(\mathrm{pH} 8.0,10$ $\mathrm{mmol} / \mathrm{L} \mathrm{MgCl}_{2}$ ), was $12.2 \times 10^{3} \mathrm{M}^{-1} \cdot \mathrm{cm}^{-1}$ [52].

\section{Analysis of fatty acid $\beta$-oxidation}

Mitochondrial and peroxisomal $\beta$-oxidation were measured in fresh liver homogenates using a modified procedure described previously by $\mathrm{Yu}$ et al. [53]. Three fatty acids (sodium salt, $1 \mathrm{mmol} / \mathrm{L}$ ), $\left[1-{ }^{14} \mathrm{C}\right]$-caprylic acid (C8:0, $0.2 \mathrm{mCi} / \mathrm{mmol}),\left[1-{ }^{14} \mathrm{C}\right]$-oleic acid $(\mathrm{C} 18: 1,0.2 \mathrm{mCi} /$ $\mathrm{mmol})$ and $\left[1-{ }^{14} \mathrm{C}\right]$-erucic acid $(\mathrm{C} 22: 1,0.1 \mathrm{mCi} / \mathrm{mmol})$ were bound to fatty acid-free BSA (5:1, molar ratio) and dissolved in the reaction medium. After termination of the reaction, radioactivity in $\mathrm{CO}_{2}$ and acid soluble products (ASP) was quantified by liquid scintillation spectrometry (LS-6500 IC; Beckman Instruments, Fullerton, $\mathrm{CA}$ ). The rate of total $\beta$-oxidation was estimated as the rate of accumulation of ${ }^{14} \mathrm{C}$ in $\mathrm{CO}_{2}$ and ASP. The rate of accumulation of ${ }^{14} \mathrm{C}$ into ASP after the addition of the inhibitors (antimycin and rotenone) represented peroxisomal $\beta$-oxidation. Mitochondrial $\beta$-oxidation was calculated to be the difference between total $\beta$-oxidation and peroxisomal $\beta$-oxidation [26].

\section{Relative quantitation of mRNA transcripts}

\section{Extraction of total RNA}

Total RNA was extracted from liver samples using guanidine isothiocynate and phenol (TRI Reagent solution, Sigma-Aldrich, St Louis, MO). Briefly, 50-100 mg of the tissue was homogenized with $1 \mathrm{~mL}$ TRI Reagent, and then $0.2 \mathrm{~mL}$ of chloroform was added to the homogenate. After centrifugation at $12,000 \times \mathrm{g}$ for $15 \mathrm{~min}$, the RNA was precipitated from the aqueous phase by addition $0.5 \mathrm{~mL}$ isopropanol followed by centrifugation again at 12,000 $\times \mathrm{g}$ for $10 \mathrm{~min}$. The pellet was washed with $75 \%$ ethanol and re-suspended in RNase-free water. The RNA then was quantified using a NanoDrop instrument (Thermo Scientific, Wilmington, DE). The integrity of isolated RNA was confirmed using $1 \%$ agarose gel electrophoresis with SYBR Safe ${ }^{\mathrm{TM}}$ DNA gel stain (Invitrogen Life Technologies, Grand Island, NY).

\section{Reverse transcription}

The RNA $(10 \mu \mathrm{g} / 50 \mu \mathrm{L})$ was treated with TurboDNase (Ambion, Austin, TX) according to the manufacturer's instruction for removal of genomic DNA. Reverse transcription was performed using $2 \mu \mathrm{g}$ of RNA using iScript ${ }^{\mathrm{TM}}$ Select cDNA Synthesis Kit (BioRad Laboratories, Hercules, CA) with random hexamer primers. Final cDNA concentrations were quantified using NanoDrop (Thermo Scientific, Wilmington, DE).

\section{Primer design}

The primers were purchased from Sigma-Aldrich and Integrated DNA Technologies, and were designed using both PrimerQuest software (Integrated DNA Technologies, Carlsbad, CA) and Primer-BLAST (NCBI). Primer oligonucleotides for $A C O$, glyceraldehyde 3-phosphate dehydrogenase (GAPDH), hepatic CPTIa, $C P T I \beta, C P T I I, m H M G C S, P P A R \alpha, A C C \alpha, A C C \beta$, and $M C D$ were designed with the pig-specific primers except CPTII (human; Supplementary Table 1). Primer pairs were selected for optimum annealing temperatures and negligible secondary structure.

\section{Real-time RT-PCR}

Real-time RT-PCR was conducted using the MyiQ Single Color Real-Time PCR Detection System (BioRad Laboratories, Hercules, CA). All samples were analyzed in triplicate. Optimal primer concentrations for each primer set were determined using a primer matrix before quantification by real-time PCR, and the linearity of amplification for each gene of interest over the 2-log range of cDNA concentrations was verified to be similar 
to that of the control gene used, GAPDH. The control gene was confirmed to be unaffected by clofibrate treatment. Reactions were performed using $12.5 \mu \mathrm{L}$ of $2 \times \mathrm{SYBR}$ Green Supermix (Bio-Rad Laboratories, Hercules, CA) contained $200 \mathrm{ng}$ of cDNA and $0.2-0.6 \mu \mathrm{M}$ of each reverse and forward primers in a final volume of 25 $\mu \mathrm{L}$. All templates were amplified for 40 cycles under the following conditions: denaturation for $30 \mathrm{~s}$ at $95^{\circ} \mathrm{C}$, primer annealing and extension for $30 \mathrm{~s}$ at $60^{\circ} \mathrm{C}$. At the end of amplification cycles, all samples were subjected to melt curve analysis to validate the absence of nonspecific products and primer dimers. Data were collected at the end of each elongation phase. The relative changes in gene expression were determined from the real-time RT-PCR data using the $2^{-\Delta \Delta \mathrm{CT}}$ method [54], where $\Delta \Delta \mathrm{C}_{\mathrm{T}}=\left(\mathrm{C}_{\mathrm{T}, \text { Target }}{ }^{-}\right.$ $\left.\mathrm{C}_{\text {T.GAPDH }}\right)_{\text {time } \mathrm{x}}-\left(\mathrm{C}_{\text {T.Target }}-\mathrm{C}_{\text {T.GAPDH }}\right)_{\text {time } 0}$.

\section{Statistical analyses}

Data from growth performance, plasma and tissue enzyme activity and gene expression assays were analyzed using the GLM procedure (SAS) according to a randomized complete block design. The model defined block (litter) treatment group and pig age as independent variables. The Tukey test was used for the multiple comparisons of means. Contrasts were used for the comparison of newborns to other age groups. The treatment and age effects and their interactions were determined according to a 3 (Con, Clo and Clo+Eto treatment) x 3 (1, 4 and $7 \mathrm{~d}$ of age) factorial arrangement. When interactions were not statistically significant, only main effects are reported. in vitro fatty acid oxidation data were analyzed using a split plot model. The treatment $\mathrm{x}$ age effects were assigned to the main plot and the fatty acid effect (C8:0, C18:1 and C22:1) was assigned to the subplot. The differences between the least squares means were assessed with the Tukey test (SAS). All values are presented as least squares means \pm SEM, and differences were declared at a $p$-value of $\leq 0.05$.

\section{Abbreviations}

Peroxisome proliferator-activating receptor- $\alpha$ $(\mathrm{PPAR} \alpha) ;$ Acyl-CoA oxidase (ACO); Carnitine palmitoyltransferase I (CPTI); Peroxisomal keto-acylCoA thiolase (KetoACoA); Malonyl-CoA decarboxylase (MCD); Acetyl-CoA carboxylase $\beta$ (ACC $\beta$ ); Mitochondrial 3-hydroxy-3-methyl-glutaryl-CoA synthase (mHMGCS); Clofibrate (Clo); Etomoxir (Eto); Control (Con); $\beta$-hydroxybutyrate (BHB); Acetoacetate (AcAc); $\mathrm{KB}$ (BHB+AcAc); Caprylic acid (C8:0); Oleic acid (C18:1); Erucic acid (C22:1).

\section{Author contributions}

Kwanseob Shim conducted the experiment and collected all samples and experimental data. He also performed all the sample assays, statistical analysis and summary as well as wrote the manuscript. Sheila Jacobi instructed and helped the sample assays. Jack Odle participated in the experiment design and data summary and edited and revised the manuscript. Lin Xi designed and organized the experiment. Lin Xi also supervised the sample assays and data statistical analysis and summary, and edited and revised the manuscript.

\section{CONFLICTS OF INTEREST}

All authors have no conflicts of interest to disclose.

\section{FUNDING}

This work was supported by National Research Initiative Competitive Grant no. 2007-35206-17897 and 2015-67015-23245 from the USDA National Institute of Food and Agriculture and by the North Carolina Agricultural Research Service.

\section{REFERENCES}

1. Girard J, Ferré P, Pégorier JP, Duée PH. Adaptations of glucose and fatty acid metabolism during perinatal period and suckling-weaning transition. Physiol Rev. 1992; 72:507-562.

2. Beiber LL, Markwell MA, Blair M, Helmrath TA. Studies on the development of carnitine palmitoyltransferase and fatty acid oxidation in liver mitochondria of neonatal pigs. Biochim Biophys Acta. 1973; 326:145-154.

3. Pégorier J, Duée P, Girard J, Peret J. Metabolic fate of nonesterified fatty acids in isolated hepatocytes from newborn and young pigs. Biochem J. 1983; 212:93-97.

4. Pégorier J, Duée P, Assan R, Peret J, Girard J. Changes in circulating fuels, pancreatic hormones and liver glycogen concentration in fasting or suckling newborn pigs. J Devel Physiol. 1981; 3:203-217.

5. Adams SH, Lin X, Yu XX, Odle J, Drackley JK. Hepatic fatty acid metabolism in pigs and rats: major differences in endproducts, $\mathrm{O} 2$ uptake, and $\beta$-oxidation. Am J Physiol. 1997; 272:R1641-R1646.

6. Yu XX, Odle J, Drackley JK. Differential induction of peroxisomal beta-oxidation enzymes by clofibric acid and aspirin in piglet tissues. Am J Physiol Regul Integr Comp Physiol. 2001; 281:R1553-R1561.

7. Heo KN, Lin X, Han IK, Odle J. Medium-chain fatty acids but not L-carnitine accelerate the kinetics of $\left[{ }^{14} \mathrm{C}\right]$ triacylglycerol utilization by colostrum-deprived newborn pigs. J Nutr. 2002; 132:1989-1994.

8. Lyvers Peffer P, Lin X, Jacobi SK, Gatlin LA, Woodworth J, Odle J. Ontogeny of carnitine palmitoyltransferase I activity, carnitine-Km, and mRNA abundance in pigs throughout growth and development. J Nutr. 2007; 137:898-903. 
9. Shim K, Lin X, Jacobi J, Odle J. Clofibrate induces expression of hepatic genes encoding fatty acid oxidation and ketogenesis enzymes in pigs during early postnatal development. The FASEB J. 2009; 23:Issue 1 supplement01 Apr 2009.

10. Nicot C, Hegardt FG, Woldegiorgis G, Haro D, Marrero PF. Pig liver carnitine palmitoyltransferase I, with low Km for carnitine and high sensitivity to malonyl-CoA inhibition, is a natural chimera of rat liver and muscle enzymes. Biochemistry. 2001; 40:2260-2266.

11. Mascaro C, Acosta E, Ortiz JA, Marrero PF, Hegardt FG, Haro D. Control of human muscle-type carnitine palmitoyltransferase I gene transcription by peroxisome proliferator-activated receptor. J Biol Chem. 1988; 273:8560-8563.

12. Ortiz JA, Mallolas J, Nicot C, Bofarull J, Rodriguez JC, Hegardt FG, Haro D, Marrero PF. Isolation of pig mitochondrial 3-hy-droxy-3-methylglutaryl-CoA synthase gene promoter: characterization of a peroxisome proliferator-responsive element. Biochem J. 1999; 337:329-335.

13. Dreyer C, Krey G, Keller H, Givel F, Helftenbein G, Wahli W. Control of the peroxisomal beta-oxidation pathway by a novel family of nuclear hormone receptors. Cell. 1992; 68:879-887.

14. Lee GY, Kim NH, Zhao ZS, Cha BS, Kim YS. Peroxisomalproliferator-activated receptor alpha activates transcription of the rat hepatic malonyl-CoA decarboxylase gene: a key regulation of malonyl-CoA level. Biochem J. 2004; 378:983-990.

15. Latruffe N, Cherkaoui Malki M, Nicolas-Frances V, Jannin B, Clemencet MC, Hansmannel F, Passilly-Degrace P, Berlot JP. Peroxisome-proliferator-activated receptors as physiological sensors of fatty acid metabolism: molecular regulation in peroxisomes. Biochem Soc Trans. 2001; 29:305-309.

16. Purdue PE, Lazarow PB. Peroxisome biogenesis. Annu Rev Cell Dev Biol. 2001; 17:701-752.

17. Braissant O, Foufelle F, Scotto C, Dauca M, Wahli W. Differential expression of peroxisome proliferatorsactivated receptors (PPARs): tissue distribution of PPAR $\alpha,-\beta$, and $-\gamma$ in the adult rat. Endocrinology. 1996; 137:354-366.

18. Ramakrishnan SK, Khuder SS, Al-Share QY, Russo L, Abdallah SL, Patel PR, Heinrich G, Muturi HT, Mopidevi BR, Oyarce AM, Shah YM, Sanchez ER, Najjar SM. PPAR $\alpha$ (peroxisome proliferator-activated receptor $\alpha$ ) activation reduces hepatic CEACAM1 protein expression to regulate fatty acid oxidation during fasting-refeeding transition. J Biol Chem. 2016; 291:8121-129.

19. Echeverría F, Ortiz M, Valenzuela R, Videla LA. Longchain polyunsaturated fatty acids regulation of PPARs, signaling: relationship to tissue development and aging. Prostaglandins Leukot Essent Fatty Acids. 2016; 114:28-34.
20. Li HH, Tyburski JB, Wang YW, Strawn S, Moon BH, Kallakury BV, Gonzalez FJ, Fornace AJ Jr. Modulation of fatty acid and bile acid metabolism by peroxisome proliferator-activated receptor $\alpha$ protects against alcoholic liver disease. Alcohol Clin Exp Res. 2014; 38:1520-1531.

21. Chandran K, Goswami S, Sharma-Walia N. Implications of a peroxisome proliferator-activated receptor alpha (PPAR $\alpha)$ ligand clofibrate in breast cancer. Oncotarget. 2016; 7:15577-15599. https://doi.org/10.18632/oncotarget.6402.

22. Cheon Y, Nara TY, Band MR, Beever JE, Wallig MA, Nakamura MT. Induction of overlapping genes by fasting and a peroxisome proliferator in pigs: evidence of functional PPAR \{alpha\} in nonproliferating species. Am J Physiol Regul Integr Comp Physiol. 2005; 288:R1525-R1535.

23. Staels B, Dallongeville J, Auwerx J, Schoonjans K, Leitersdorf E, Fruchart JC. Mechanism of action of fibrates on lipid and lipoprotein metabolism. Circulation. 1998; 98:2088-2093.

24. Luci S, Giemsa B, Kluge H, Eder K. Clofibrate causes an upregulation of PPAR-\{alpha\} target genes but does not alter expression of SREBP target genes in liver and adipose tissue of pigs. Am J Physiol Regul Integr Comp Physiol. 2007; 293:R70-R77.

25. Peffer PL, Lin X, Odle J. Hepatic beta-oxidation and carnitine palmitoyltransferase $\mathrm{I}$ in neonatal pigs after dietary treatments of clofibric acid, isoproterenol, and medium-chain triglycerides. Am J Physiol Regul Integr Comp Physiol. 2005; 288:R1518-R1524.

26. Bai X, Lin X, Drayton J, Liu Y, Ji C, Odle J. Clofibrate increases long-chain fatty acid oxidation by neonatal pigs. $\mathrm{J}$ Nutr. 2014; 144:1688-1693.

27. Lin X, Jacobi S, Odle J. Transplacental induction of fatty acid oxidation in term fetal pigs by the peroxisome proliferator-activated receptor alpha agonist clofibrate. J Anim Sci Biotechnol. 2015; 6:11.

28. Hostetler CE, Knauer MT. Industry productivity analysisSow farm traits. J Anim Sci. 2012; 90 Suppl. 3/J.

29. Baker VA, Harries HM, Waring JF, Duggan CM, Ni HA, Jolly RA, Yoon LW, De Souza AT, Schmid JE, Brown RH, Ulrich RG, Rockett JC. Clofibrate-induced gene expression changes in rat liver: a cross-laboratory analysis using membrane cDNA arrays. Environ Health Perspect. 2004; 112:428-438.

30. Yu XX, Odle J, Drackley JK. Differential induction of peroxisomal beta-oxidation enzymes by clofibric acid and aspirin in piglet tissues. Am J Physiol Regul Integr Comp Physiol. 2001; 281:R1553-R1561.

31. Ouali F, Djouadi F, Merlet-Bénichou C, Riveau B, Bastin J. Regulation of fatty acid transport protein and mitochondrial and peroxisomal beta-oxidation gene expression by fatty acids in developing rats. Pediatr Res. 2000; 48:691-696.

32. Cabrero A, Merlos M, Laguna JC, Carrera MV. Downregulation of acyl-CoA oxidase gene expression and 
increased NF-kappaB activity in etomoxir-induced cardiac hypertrophy. J Lipid Res. 2003; 44:388-398.

33. Ito Y, Yamanoshita O, Kurata Y, Kamijima M, Aoyama T, Nakajima T. Induction of peroxisome proliferator-activated receptor alpha (PPARalpha)-related enzymes by di(2ethylhexyl) phthalate (DEHP) treatment in mice and rats, but not marmosets. Arch Toxicol. 2007; 81:219-226.

34. Nicot C, Relat J, Woldegiorgis G, Haro D, Marrero PF. Pig liver carnitine palmitoyltransferase. Chimera studies show that both the $\mathrm{N}$ - and $\mathrm{C}$-terminal regions of the enzyme are important for the unusual high malonyl-CoA sensitivity. J Biol Chem. 2002; 277:10044-10049.

35. Hegardt FG, Serra D, Asins G. Influence of etomoxir on the expression of several genes in liver, testis and heart. Gen Pharmacol. 1995; 26:897-904.

36. Huang WY, Kummerow FA. Cholesterol and fatty acid synthesis in swine. Lipids. 1976; 11:34-41.

37. Pullen DL, Liesman JS, Emery RS. A species comparison of liver slice synthesis and secretion of triacylglycerol from nonesterified fatty acids in media. J Anim Sci. 1990; 68:1395-1399.

38. Lin X, Shim K, Odle J. Carnitine palmitoyltransferase I control of acetogenesis, the major pathway of fatty acid \{beta\}-oxidation in liver of neonatal swine. Am J Physiol Regul Integr Comp Physiol. 2010; 298:R1435-R1443.

39. Dyck JR, Cheng JF, Stanley WC, Barr R, Chandler MP, Brown S, Wallace D, Arrhenius T, Harmon C, Yang G, Nadzan AM, Lopaschuk GD. Malonyl coenzyme a decarboxylase inhibition protects the ischemic heart by inhibiting fatty acid oxidation and stimulating glucose oxidation. Circ Res. 2004; 94:e78-e84.

40. Esfandiari F, You M, Villanueva JA, Wong DH, French SW, Halsted CH. S-adenosylmethionine attenuates hepatic lipid synthesis in micropigs fed ethanol with a folate-deficient diet. Alcohol Clin Exp Res. 2007; 31:1231-1239.

41. Liu Z, Liu W, Huang Y, Guo J, Zhao R, Yang X. Lipopolysaccharide significantly influences the hepatic triglyceride metabolism in growing pigs. Lipids Health Dis. 2015; 14:64.

42. Oh SY, Park SK, Kim JW, Ahn YH, Park SW, Kim KS. Acetyl-CoA carboxylase beta gene is regulated by sterol regulatory element-binding protein-1 in liver. J Biol Chem. 2003 Aug 1; 278:28410-28417.

43. Campbell FM, Kozak R, Wagner A, Altarejos JY, Dyck JR, Belke DD, Severson DL, Kelly DP, Lopaschuk GD. A role for peroxisome proliferator-activated receptor alpha (PPARalpha) in the control of cardiac malonyl-CoA levels: reduced fatty acid oxidation rates and increased glucose oxidation rates in the hearts of mice lacking PPARalpha are associated with higher concentrations of malonyl-CoA and reduced expression of malonyl-CoA decarboxylase. J Biol Chem. 2002; 277:4098-4103.

44. Kruszynska YT, Sherratt HS. "Glucose kinetics during acute and chronic treatment of rats with 2[6(4-chlorophenoxy)hexyl]oxirane-2-carboxylate, etomoxir". Biochem Pharmacol. 1987; 36:3917-3921.

45. Luiken JJ, Niessen HE, Coort SL, Hoebers N, Coumans WA, Schwenk RW, Bonen A, Glatz JF. Etomoxir-induced partial carnitine palmitoyltransferase-I (CPT-I) inhibition in vivo does not alter cardiac long-chain fatty acid uptake and oxidation rates. Biochem J. 2009; 419:447-455.

46. Natarajan SK, Eapen CE, Pullimood AB, Balasubramanian KA. Oxidative stress in experimental liver microvesicular steatosis: role of mitochondria and peroxisomes. J Gastroenterol Hepatol. 2006; 21:1240-1249.

47. Gornall AG, Bardawill CJ, David MM. Determination of serum proteins by means of the biuret reaction. J Biol Chem. 1949; 177:751-766.

48. Kientsch-Engel RI, Siess EA. D-(-)-3-hydroxybutrate and acetoacetate. In: Methods of Enzymatic Analysis (Bergmeyer HU, editors) VCH Publishers, Deerfield Beach, FL. 1985; pp. 60-99.

49. Bremer J. The effect of fasting on the activity of liver carnitine palmitoyltransferase and its inhibition by malonylCoA. Biochim Biophys Acta. 1981; 665:628-631.

50. Walusimbi-Kisitu M, Harrison EH. Fluorometric assay for rat liver eroxisomal fatty acyl-coenzyme A oxidase activity. J Lipid Res. 1983; 24:1077-1084.

51. Quant PA, Tubbs PK, Brand MD. Treatment of rats with glucagon or mannoheptulose increases mitochondrial 3-hydroxy-3-methylglutaryl-CoA synthase activity and decreases succinyl-CoA content in liver. Biochem J. 1989; 262:159-164.

52. Lowe DM, Tubbs PK. Succinylation and inactivation of 3-hydroxy-3-methylglutaryl-CoA synthase by succinyl$\mathrm{CoA}$ and its possible relevance to the control of ketogenesis. Biochem J. 1985; 232:37-42.

53. Yu XX, Drackley JK, Odle J. Rates of mitochondrial and peroxisomal $\beta$-oxidation of palmitate change during postnatal development and food deprivation in liver, kidney and heart of pigs. J Nutr. 1997; 127:1814-1821.

54. Livak KJ, Schmittgen TD. Analysis of relative gene expression data using real-time quantitative PCR and the 2(-Delta Delta C(T)) method. Methods. 2001; 25:402-408. 